IZA DP No. 4977

Real Wages, Working Time, and the Great Depression: What Does Micro Evidence Tell Us?

Robert A. Hart

J. Elizabeth Roberts

May 2010 


\title{
Real Wages, Working Time, and the Great Depression: What Does Micro Evidence Tell Us?
}

\author{
Robert A. Hart \\ University of Stirling \\ and IZA
}

\author{
J. Elizabeth Roberts \\ University of Stirling
}

\author{
Discussion Paper No. 4977 \\ May 2010 \\ IZA \\ P.O. Box 7240 \\ 53072 Bonn \\ Germany \\ Phone: +49-228-3894-0 \\ Fax: +49-228-3894-180 \\ E-mail: iza@iza.org
}

Any opinions expressed here are those of the author(s) and not those of IZA. Research published in this series may include views on policy, but the institute itself takes no institutional policy positions.

The Institute for the Study of Labor (IZA) in Bonn is a local and virtual international research center and a place of communication between science, politics and business. IZA is an independent nonprofit organization supported by Deutsche Post Foundation. The center is associated with the University of Bonn and offers a stimulating research environment through its international network, workshops and conferences, data service, project support, research visits and doctoral program. IZA engages in (i) original and internationally competitive research in all fields of labor economics, (ii) development of policy concepts, and (iii) dissemination of research results and concepts to the interested public.

IZA Discussion Papers often represent preliminary work and are circulated to encourage discussion. Citation of such a paper should account for its provisional character. A revised version may be available directly from the author. 


\section{ABSTRACT \\ Real Wages, Working Time, and the Great Depression: What Does Micro Evidence Tell Us?}

Based largely on industry-level aggregate statistics, the prevailing view, and one that has strongly influenced macroeconomic thought, is that real wages during the cycle containing the Great Depression are either acyclical or countercyclical. Does this finding hold-up when more micro data are employed? We examine this question based on detailed blue-collar workers' company payroll data for a large section of the British engineering and metal working industries. We distinguish between pieceworkers and timeworkers, with pieceworkers accounting for over half the workforce. For the period 1927 to 1937, the two pay groups are broken down into 14 occupations, and 48 travel-to-work geographical districts. We estimate wage and hours cyclicality in respect of the national unemployment rate as well as the district rates. Weekly hours and real weekly earnings are found to be strongly procyclical. Real hourly earnings of pieceworkers are also significantly procyclical. The roles of standard and overtime hours are crucial to these findings.

JEL Classification: $\quad$ E32, J31, J33, N64

Keywords: real wage cyclicality, working time, piecework, timework, the Great Depression

Corresponding author:

Robert A. Hart

Division of Economics

University of Stirling

Stirling FK9 4LA

Scotland

United Kingdom

E-mail: r.a.hart@stir.ac.uk

\footnotetext{
* Work on this research was funded by ESRC Grant RES-000-22-3574. We are grateful to the Engineering Employers' Federation (EEF) for allowing access to their payroll records and to Warwick University Modern Record Centre and Glasgow University Archive Centre for their help in assembling the data. We thank Andrew Currall for transcribing the data. We also thank Paul Devereux, Olaf Hübler, and Gary Solon for very helpful comments on an earlier draft. The full EEF data base, containing all EEF data and accompanying unemployment rates used in this project, is available at the UK Data Archive, Study 5569 (http://www.data-archive.ac.uk/searchStart.asp).
} 


\section{Introduction}

From the 1930s through to the 1980s, the prevailing view among macroeconomists was that the relationship between real wage movements and the business cycle is relatively weak. Most of the influential theory supported the notion of countercyclical or acyclical real wages with relatively few mainline contributions proposing real wage procyclicality. The weight of empirical findings over this earlier period also lends support to these outcomes. ${ }^{1}$ Starting with Bils (1985), a radical shift in opinion has taken place. The new stylised fact is that real wages are strongly procyclical. This turnaround has been driven by empirical measurement rather than macro theory. ${ }^{2}$ Arguably, there have been three key developments. First and foremost, the last three decades have witnessed substantial improvements both in the availability of longitudinal micro data sets and the formulation of microeconometric techniques. This has allowed researchers, for example, to tackle problems of workforce compositional biases that are tied-up with more aggregative data. Second, and much more simply, more care has been given to defining worker remuneration in studies of real wage movements. Thirdly, greater attention has been devoted to the representation of the business cycle itself.

The formulation of macro wage theories has inevitably been strongly influenced by the single most important cycle of recent economic history, the 1927 to 1937 cycle that covered the period of the Great Depression. One of the best known U.S. empirical studies, based on monthly

\footnotetext{
${ }^{1}$ For reviews of the theoretical and empirical literature on real wages and the cycle from Keynes onwards see Bernanke and Powell (1986), Barsky and Solon (1989), Carlin and Soskice (1990, Chapter 16), Solon, Barsky, Parker (1994), Abraham and Haltiwanger (1995), and Swanson (2007).

2 Although, see Pissarides (2009) who develops a search and matching model that is strongly compatible with the new micro evidence on real wages. The author also provides a comprehensive survey of North American and European mirco empirical studies of real wage cyclicality.
} 
data for eight manufacturing industries, is that of Bernanke and Powell (1986). They find support for countercyclical manufacturing real hourly wage earnings in this period and for highly procyclical real weekly earnings and weekly hours. A strength of this work is the use of comparatively disaggregated data. Here, we move significantly further in the direction of micro breakdowns. We explore an important data set of blue collar workers employed in firms belonging to the British Engineering Employers’ Federation (EEF), Britain’s foremost employers’ organisation. ${ }^{3}$ From 1926 to 1968, the Federation asked each member firm to undertake detailed annual earnings enquiries based on its payroll records. We make use of the data from 1927 to 1937 . This covers the cycle represented by the national unemployment rate in Figure 1, consisting of the weighted averages of the geographical EEF district rates. During this time, the Federation represented between 1,800 and 2,200 firms operating in the most important sectors of British manufacturing industry. ${ }^{4}$ Over the period of study, they employed between 390,000 and 520,000 adult male manual workers (Wigham, 1973, Appendix, J), numbers that represented about 30\% of employment in the British engineering, metal working, automotive, and aircraft industries. In total (i.e. covering EEF and non-EEF firms), these sectors comprised about 25\% of British manufacturing industry.

The primary focus of the payroll data is on the occupational pay and hours. A big advantage of these statistics, even by modern standards, is that they distinguish between

\footnotetext{
${ }^{3}$ The Employers' Federation of Engineering Associations was established in 1896 and by 1899 had become known as the Engineering Employers' Federation. It later merged in 1918 with the National Employers' Federation and became known as the Engineering and Allied Employers' National Federation. In 1961 it changed its name back to the Engineering Employers' Federation. It is the largest British sectoral employers' association with a current membership of nearly 6,000 firms.

4 The complete coverage of EEF industrial coverage, occupations, engineering sections, and geographical districts is presented in Table 1.
} 
pieceworkers and timeworkers. Each of these pay groups is subdivided into 14 manual occupations, and 48 EEF travel-to-work districts. The information allows us to break down weekly wage earnings into hourly pay and weekly hours. In the case of timeworkers, the latter distinguish between weekly standard (or straight-time) and weekly overtime hours.

We show that average weekly hours and average weekly real earnings of both pieceworkers and timeworkers were strongly procyclical over this period. Our estimated weekly earnings-unemployment elasticities are on a par with hourly earnings-unemployment elasticities from modern micro longitudinal panels. Our principal explanation for this finding is that, relative to the somewhat cumbersome processes of setting piece-rates and wage-rates, changes in weekly hours offered employers a direct, simple, and effective means of adjusting both payroll costs and output in the face of exceptionally strong business cycle fluctuations. We also find that hourly real wage earnings of pieceworkers are significantly procyclical. This is in line with recent U.S. evidence that suggests that incentive pay is especially procyclical. In the context of the Great Depression in Britain, it is not a trivial finding. Piece rates constituted a major payments method among British blue-collar inter-war manufacturing occupations, accounting for over half of workers in the EEF during the period of study. Depending on the underlying regression specification, timeworkers' hourly real wages are found, by contrast, to be either weakly procyclical or acyclical while their standard real wage rates are unequivocally acyclical.

\section{Payment methods, hours of work, and the business cycle}

In this section, we discuss the issues motivating our subsequent empirical investigation of the behavior of hours and wages over the cycle. The Appendix offers a slightly more formal representation of several key points raised in the discussion. 


\section{Rates of pay versus hours of work adjustments}

Why might we expect adjustments of working hours to be relatively more important than adjustments of hourly rates of pay in the determination of of earnings changes in our inter-war payroll data? There are three main reasons.

(a) Compared to altering wage rates and piece rates, changing weekly hours of work provided a direct and simple firm-level means of adjusting labor inputs and labor costs to large and rapid changes in product prices and product demand. Wage rate setting was subject to a three-tier bargaining process, embracing national- ${ }^{5}$, district-, and firm-level employer-union negotiations. ${ }^{6}$ Even with piece rates, involving a far more complex remuneration structure, there were national-level attempts at establishing pricing guidelines. ${ }^{7}$

(b) Weekly manufacturing industry hours in inter-war Britain were high relative to the post-war era. This offered employers considerable scope to maintain viable production levels while at

\footnotetext{
${ }^{5}$ Engineering pay setting during WWI had a major bearing on tendencies towards national-level bargaining in later years. The National Wages Agreement of 1917 introduced an arbitration system that adjudicated three times a year in respect of national uniform wage increases as well as engineering district rates. Although the Agreement ceased in 1920, national-level bargaining continued up to 1948. Also during WWI, a bonus was granted to engineering workers due to the increased cost of living during the war. This was intended to be a temporary measure but, although significantly reduced in 1922, it continued to be paid over the inter-war period.

${ }^{6}$ National agreements determined annual standard time rates for skilled fitters and laborers. These were then used to establish relative wages for other skill groups. But subsequent districtlevel and firm-level bargaining produced a multiplicity of deviations from these national rates in order to accommodate local market conditions.

${ }^{7}$ Based on a worker with 'average ability', national agreements established a percentage mark-up that a pieceworker might be expected to earn compared with the standard time rate within the same occupation. As with time rates, however, local conditions dictated that piece rates, as well as piece rate - time rate differentials, varied substantially within firms, across firms and through time.
} 
the same time effecting significant reductions in the length of the workweek and, therefore, in the sizes of their payrolls. ${ }^{8}$

(c) For many firms, hours cuts offered large marginal falls in per unit labor costs because overtime hours were paid for at highly favorable rates. ${ }^{9}$

Piece work and time work

In his U.S. work on employment and earnings during the Great Depression, Bernanke (1986, p.106, Appendix Note 1) makes explicit reference to the fact that his earnings data are based on a mix of timeworkers and pieceworkers. Between 1927 and 1937, 53\% of the British EEF workforce was paid piece rates and $47 \%$ time rates. Apart from their respective quantitative importance, there are four strong reasons for separating timeworkers and pieceworkers in the study of wage cyclicality.

${ }^{8}$ During the inter-war period, the maximum length of the standard workweek was 47 hours throughout the EEF. Weekly hours beyond 47 were paid at premium overtime rates. From Table 2 we find that between 1927 and 1937 the weighted average of timeworkers weekly hours was 49.1 and pieceworkers 47.5 . Average total weekly hours dropped considerably for both groups during the early Depression years (1930-32), falling short of 47 hours by 0.5 hours (timeworkers) and 1.8 hours (pieceworkers). In the post-Depression period (1934-1937), the two payment groups averaged, respectively, 3.9 and 2.2 hours of weekly overtime. In the older traditional engineering districts, located mainly in the north of Britain, average hours fluctuations were considerably greater.

9 Throughout all EEF member firms, weekly standard hours were divided into 'standard days' (5 weekdays and Saturday mornings) and overtime pay applied to daily hours in excess of the laiddown standard daily hours. Both timeworkers and pieceworkers received premium pay for overtime hours. The calculation for a pieceworker was based on a mark-up of his so-called minimum piecework standard. From 1920 to 1930, overtime was typically paid at time and a half 'basic' rates if worked on Mondays to Saturdays and at double time for Sundays and public holidays. From 1931 to 1946, the first two hours of daily overtime were paid at time and a quarter and subsequent hours at time and a half. The rules of overtime payments are described in detail in Knowles and Hill (1954). 
i) Since in the short-term piece-rated pay is linked more closely to output than time-rated pay, we might expect the former to exhibit more responsiveness to business cycle fluctuations than the latter. Based on the Panel Study of Income Dynamics (PSID), Devereux (2001) finds that hourly earnings responses of individuals whose pay is linked directly to output (including piece-rates) are significantly more procyclical than those of hourly paid and salaried workers. Based on pre- and post-war EEF data, Hart (2008) also finds significantly greater inter-war hourly wage procyclicality among pieceworkers compared to timeworkers, though less pronounced than in Devereux's study.

ii) As illustrated in Appendix (a), there is a potential problem of workforce composition bias in the estimation of wage cyclicality. If lower ability, lower paid workers are more likely to be laid off during a recessionary downturn and dominate new hiring during the subsequent upturn then this introduces a countercyclical bias when using aggregate wage measures. Following Lazear (1986) and Brown (1990), suppose that workers know their own productivity but firms do not. More able workers self select into a piece-rated system since they are likely to judge that the value of their hourly productivity exceeds the hourly timerate for equivalent work plus the imputed hourly monitoring cost related to piece work. By an equivalent argument, less able workers self-select into time-rated jobs. So, if workers on piece-rates are clustered at the top end of the ability spectrum and workers on time-rates at lower levels then this reduces then, where there is a choice between piece rated and time rated labor inputs, we might expect, a priori, that timeworkers are more likely to exhibit such biases. There is a counter argument, however. Ceteris paribus composition bias may be greater among pieceworkers than timeworkers. Piece work introduces a requirement to 
monitor each individual's output per period and thereby provides records on which systematically to rank employees by productive performance

iii) Consider the method of pay between the two groups. Weekly wage earnings of timeworkers at time $t, E_{t}^{T}$, is given by

\section{(1) $\quad E_{t}^{T}=e_{t} \cdot H_{t}$}

where $e_{t}$ is average hourly earnings and $H_{t}$ is average weekly hours. Procyclical hours correlate positively with both weekly pay and, given overtime working, hourly pay. In other words, the intensive margin effects of hours on the weekly and hourly pay of timeworkers are unequivocally procyclical. ${ }^{10}$ Weekly earnings of pieceworkers, $E_{t}^{P}$, is given by

\section{(2) $\quad E_{t}^{P}=\pi_{t} \cdot Z_{t}\left(H_{t}, \theta_{t}\right)$}

where $Z_{t}$ indexes performance, $\pi_{t}$ is the piece rate, and $\theta_{t}$ is work effort. In contrast to time work, the net intensive margin effects on the cyclicality of piecework pay is uncertain. It depends on whether hours and effort act as complements or substitutes (Pencavel, 1977; Hart, 2008).

iv) As illustrated in Appendix (b), the problem of composition bias among skilled workers may be exacerbated due to intensive margin effects. During a cyclical downturn, actual pay of skilled workers may be less responsive to the cycle than that of the less skilled if

\footnotetext{
${ }^{10}$ Let hourly earnings be expressed as a geometric average, with $w$ representing the standard hourly rate and the overtime premium fixed at $\mathrm{k}_{0}$ (e.g. one-and-a-half times the standard rate). We have $e=w^{\lambda}\left(k_{0} \cdot w\right)^{(1-\lambda)}$ where $\lambda=h_{s} / h \leq 1$ and where $(1-\lambda)$ is the share of standard weekly hours $\left(h_{s}\right)$ to total hours. Let the rate of unemployment, $\mathrm{U}$, proxy the cycle. Then, taking logs, rearranging, and expressing in terms of time $t$, differentiation with respect to $U_{t}$ yields: $d \operatorname{loge}_{t} / d U_{t}=d \log _{t} / d U_{t}+\log k_{0}\left[d(1-\lambda) / d U_{t}\right]$. Since the share of overtime, $(1-\lambda)$, is procyclical this increases the procyclicality of hourly wage earnings compared with hourly wage rates.
} 
firms show a propensity to hoard skilled labor inputs in order to protect sunk investments. ${ }^{11}$ However, this effect is likely to be less potent in the case of piece work where pay relates directly to actual productivity per period. In other words, the distinction between paid for and effective working time is less meaningful when remuneration is linked directly to performance.

\section{National bargaining, local bargaining, and the cycle}

The predominant approach in the literature has been to concentrate on a national cyclical indicator, typically the national rate of unemployment, to reflect business cycle effects that inform pay decisions. Given some degree of national bargaining in the EEF, we also make use of the national rate. However, we know that for both wage rates and piece rates local bargaining contributed importantly to final pay settlements. ${ }^{12}$ Older traditional engineering industries (such as textile engineering, heavy engineering, marine engineering) were concentrated in the north of Britain, with specific industries tending to cluster in specific districts. Midland and southern engineering districts, by contrast, enjoyed significant concentrations of modern industries (car manufacture, aircraft construction, related light engineering), again with high degrees of specific geographical clustering. So, in important respects, local collective bargaining was conducted in distinctly different product and labor markets. At least in the short-run, capital and labor

\footnotetext{
${ }^{11}$ For example, skilled fitters in the EEF would normally have served a 5-7 year apprenticeship in sharp contrast to laborers who required minimal training.

${ }^{12}$ Knowles and Hill (1954) succinctly summarise the position for each payment method. In the case of time rates, they conclude: "All rates fixed by national agreement are essentially minima, the national-agreed differentials may be disturbed or even inverted by firms paying more than the minima all round". For piece rates, they conclude: "Owing to the immense number of different processes and operations in so heterogeneous an industry, as well as to the rapidity of technical development, any general control over piece-work earnings can be no more than minimal...”
} 
mobility were not serious concerns due both to the severity of the Depression and to occupational and skill mismatches. Under these circumstances, we would expect that local conditions played an important - perhaps the predominant - role in bargaining outcomes over pay. Accordingly, we also study the influence of district unemployment rates on pay and hours cyclicality.

\section{The Engineering Employers' Federation Payroll Data: 1927-1937}

The EEF's payroll statistics were collected, in part, for the purpose of providing detailed data on pay as background to employer-union negotiations at national, district, and firm levels. Statistics cover a specimen week in each October. Virtually all member firms were unionized ${ }^{13}$ and somewhat skewed towards larger employers. ${ }^{14}$ We concentrate on manual males aged 18 and over. During the 1920s and 1930s, the EEF embraced a wide range of engineering, metal, aircraft, and automotive firms. Table 1 shows its inter-war industrial coverage, based on the Ministry of Labour's industrial classification. Figure 2 shows that, over our study period, all firms contributing to this industrial classification (i.e. EEF and non-EEF firms) accounted for about $25 \%$ of British manufacturing industry. Of this $25 \%$, EEF firms represented about $30 \%$. Our recorded data cover between $10 \%$ and $15 \%$ of this EEF share.

\footnotetext{
${ }^{13}$ Wigham (1973) indentifies three union-related basic functions of the Federation. First, it provided collective support in order to protect individual firms from being singled out in union actions. Second, it aimed to preserve the relative power of employers to make management decisions. Third, it helped towards conflict resolution in union disputes.

${ }^{14}$ Hill and Knowles (1956) have undertaken a detailed analysis of the 1953 membership of the EEF. They show that while 50.7 of federated firms employed fewer than 100 workers, they accounted for only 6.2 per cent of total employment. By contrast, the 1.8 percent of firms that employed over 3,000 workers accounted for $27 \%$ of total employment.
} 
Payroll data on pieceworkers and timeworkers are recorded separately. For timeworkers, pay and hours statistics are made up of standard hourly wage rates (excluding overtime), hourly and weekly earnings (including overtime), and weekly hours of work. For pieceworkers, we have weekly and hourly earnings, and weekly hours. Table 1 identifies the EEF occupations, geographical districts, and engineering sections. While wages and hours data are not available at the level of the individual worker, they provide a level of micro detail that is unmatched by other data sets of this era. They consist of cell means. Each cell is defined by a pay or hours measure of either pieceworkers or timeworkers at a give annual time period delineated by one of 14 occupations and one of 48 engineering districts. For a shorter time period, we also have data for 28 engineering sections. ${ }^{15}$ Table 2 indicates the average number and standard deviation of workers (summed across all occupations and both payment methods) in each district over the entire period of study and over the Depression years. There are wide variations in these numbers, ranging from 1800 in London to 57 in Wigan.

Table 2 presents a summary of the hours' statistics for the whole period. Average weekly total and overtime hours of timeworkers are higher than their pieceworker equivalents. However, it is clear from the large standard deviations that there were wide variations around these means. Differences in working time at district level are illustrated in Figure 3 in respect of timeworkers. In the relatively prosperous midlands and southern districts of Coventry and London - where the modern light engineering, automotive and aircraft firms clustered - average weekly hours always exceeded the maximum standard hours, even during the depth of the

\footnotetext{
${ }^{15}$ We do not have section-level statistics by district. Including first differencing, district-level breakdowns are available for the whole 1927 - 1937 cycle. The section-level data are only available from 1930 and so allow analysis from 1931 to 1937 . We have undertaken all the later empirical work at section level, obtaining results that are largely in line with our findings based on the full cycle of district-based data. We concentrate here on our superior data set.
} 
Depression. In the north, large cities like Liverpool and Manchester averaged hours slightly below 47 during the peak of the Depression. Other districts, like Blackburn in the north, experienced extremely large reductions in hours below the 47 standard hours ceiling. Figure 4 shows the share of overtime within total hours for three important occupations - time-rated turners, sheet metal workers, and laborers. The shares are strongly procyclical.

Table 3 shows means and coefficients of variations of timeworkers' real standard hourly pay and weekly hours during the Depression (1930-33) and the post-Depression (1934-37) years. It covers a selection of districts, occupations and sections. Coventry is a city dominated by car manufacture and light engineering. Overtime was worked, on average, throughout the Depression years. In fact, average hours rose by only 3\% between the Depression and postDepression periods. Average real standard wage rates in Coventry and its associated motors/cars/cycles section rose, respectively, by $11.6 \%$ and $16.2 \%$ between the two periods. By contrast, the far less prosperous North East Coast of England is closely associated with the marine engineering section of the EEF. Average weekly hours rose between Depression and post-Depression years by $8.7 \%$ and by $6.3 \%$ in this district and this section, respectively. Real wage growth was considerably behind Coventry, at $7.1 \%$ and $9.6 \%$. The manufacturing activity of Halifax in the north of England was dominated by textile production, an older industry severely adversely affected by the Depression. Its average hours rose by $16 \%$ between the Depression and post-Depression periods while real standard wages grew by a modest $4.6 \%$.

Against the background of manufacturing unemployment, Figure 5 provides an aggregate summary of pieceworkers' and timeworkers' hours and pay (nominal and real) as well as final output and retail price deflators over the period 1927 to 1937. Average weekly hours of both groups are strongly procyclical. On the downside of the cycle and towards the end of the cycle, 
pieceworkers' weekly hours were considerably below those of timeworkers. Final output and retail prices fell significantly between 1928 and 1934 - by $13.5 \%$ and $12.1 \%$, respectively. Nominal hourly earnings of pieceworkers declined during the early years of the Depression while equivalent earnings of timeworkers were flat. Price deflation ensured that average real hourly earnings of pieceworkers were very slightly positive in the early years while those of timeworkers displayed more appreciable growth. Due to the large aggregate downward movement in weekly hours, nominal weekly earnings of both groups are clearly procyclical, although somewhat less markedly so in the case of timeworkers. Real weekly earnings of pieceworkers appear procyclical at this aggregate level. For timeworkers, real weekly earnings fell slightly between 1929 and 1930 and thereafter were flat before displaying annual growth. Of course, we cannot infer degrees, or even directions, of wage cyclicality from these aggregate pictures. We need to unwind wage, hours and unemployment experiences across widely differing occupations and geographical districts of the EEF, while controlling for fixed effects, in order to achieve clearer insights.

Table 2 also shows the piecework-timework hourly earnings differentials for the period, together with the changes in weekly hours and real weekly earnings for the two groups of workers. Average hourly earnings of pieceworkers were $25 \%$ higher than timeworkers over the period. A positive earnings differential between these payment methods is a common finding in the literature (e.g. Pencavel, 1977; Seiler, 1984). ${ }^{16}$ Figure 6 shows the weekly pieceworkertimeworker earnings differentials (in logs) for each year between 1927 and 1937. The

\footnotetext{
${ }^{16}$ Note, however, that this aggregate figure is not comparing like-with-like jobs. One major influence is structural. There was a greater incidence of pieceworking in the more modern/higher wage firms located in southern/midland districts. In our complete data, $43 \%$ of workers in northern districts worked on piece rates compared to $63 \%$ in south/midlands districts.
} 
differential is procyclical. The equivalent weekly hours differential, in Figure 7, is also procyclical.

As identified in Table 2, we have matching unemployment rates for 28 of our 48 engineering districts. ${ }^{17}$ These include virtually all the main centers of engineering, metal working, automotive and aircraft industries that comprise EEF membership. Figure 8 shows wide diversities among unemployment rates across a sample of 5 of these districts. London and Coventry rates never exceeded 20\% while Oldham and Liverpool reached rates in excess of $30 \%$.

\section{Estimation}

We illustrate our estimating equations with respect to real weekly earnings of pieceworkers, $E^{P}$. Comparable estimation is undertaken for timeworkers (i.e. $E^{T}$ ) as well as with respect to real hourly earnings $(e)$ and weekly hours $(H)$ for the two pay groups and with respect to the real hourly standard wage $(w)$ for timeworkers.

Our first estimation approach concentrates on national-level bargaining. Accordingly, it incorporates the national unemployment rate as our proxy for the cycle. The aggregate EEF unemployment series is graphed in Figure 1. We compare results of wages deflated by the consumer price index and by a final output price index. It is well known that outcomes may be sensitive to the choices of price indices (for example, Bernanke and Powell, 1986; Abraham and Haltiwanger, 1995).

For occupation $j$ in district $r$ at time $t$, the step 1 estimating equation is given by

\footnotetext{
${ }^{17}$ Most of the district unemployment rates are obtained from Hart and MacKay (1975). They were constructed to coincide with EEF districts by combining data on male unemployment and total insured workers taken from the Local Unemployment Index and from other records provided by the Department of Employment. A few district series are obtained from issues of the Ministry of Labour Gazette.
} 
(3) $\Delta \log E_{j r t}^{P}=d_{j}+d_{r}+\sum_{t=1}^{T} \eta_{t} d_{t}+u_{j r t}$

where $d_{j}$ is an occupation dummy, $d_{r}$ is a district dummy and where $d_{t}$ is a time dummy equal to 1 if the observation is from year $t$, and $u_{j r t}$ is an error term. The estimated coefficients on the time dummies, $\hat{\eta}_{t}(t=1, \ldots . T)$, are then regressed in step 2 on the change in the national unemployment rate and a time trend, $Y E A R_{t}$, or

(4) $\hat{\eta}_{t}=\beta_{1}+\beta_{2} \Delta U_{t}+\beta_{3} Y E A R_{t}+v_{t}$.

We estimate (3) by OLS and (4) by WLS where the weights in the second stage are the number of individuals represented in each year. The change in the log earnings is multiplied by 100. The estimated coefficient $\beta_{2}$ then reflects the percentage change in the wage for a one-point change in the unemployment rate.

Our second specification focuses on area-specific bargaining and therefore incorporates district unemployment rates as the representation of the cyclical influences. In this instance, price changes are controlled for through the fact that the regressions incorporate both industry and time fixed effects (see Blanchflower and Oswald, 1994). As with the use of the national unemployment rate, we have a clustering problem using district rates because within a given district different occupations may share common components of variance that are not captured by the district rate.

So, we again adopt the 2-step method. We have in step 1

(5) $\Delta \log E_{j r t}^{P}=d_{j}+\sum_{t=1}^{T} \sum_{r=1}^{R} \psi_{r t} d_{r t}+\varepsilon_{j r t}$ 
where $d_{j}$ is an occupational dummy, $d_{r t}$ is a district dummy that takes the value of 1 for district $r$ at time $t$ (over $R$ districts and $T$ time periods) and $\varepsilon_{j r t}$ is an error term. In step 2, estimates of $\psi_{r t}$ are regressed on the change in district-level unemployment rates $\left(\Delta U_{r t}\right)$ plus section and time intercepts

(6) $\hat{\psi}_{r t}=b_{1} \Delta U_{r t}+d_{r}+d_{t}+v_{s t}$.

Therefore, we now fully account for occupation, district, and time fixed effects. Examples of district effects include industrial composition, the vintage of capital, occupational skill-mix, the strength of union representation. We estimate (5) by OLS and (6) by WLS where the weights in the second stage are the number of individuals in each district in each year.

\section{Findings}

(a) General

Starting with the single national EEF unemployment rate, the top half of Table 4 presents separate timeworker and pieceworker estimates of cyclicality based on equations (3) and (4). No significant differences are found between choices of price deflator. Weekly hours and real weekly earnings are strongly procyclical and not statistically different between the two pay groups. A one point increase in the rate of unemployment is associated with a 1 percentage reduction in weekly real earnings. These estimates are on a par with the modern North American and European micro estimates with respect to the hourly earnings of job stayers (Pissarides, 2009, Tables II and III). Real hourly earnings are also procyclical and not significantly different between the two pay groups. However, the pieceworker estimates are especially well fitted and indicate that a one point increase in the rate of unemployment is associated a 0.3 percentage 
reduction in real hourly earnings. In the case of timeworkers, since real standard hourly pay of timeworkers is found to be acyclical it is clear that earnings procyclicality is driven by hours procyclicality.

Equations (5) and (6) incorporate district unemployment rates and focus on area-specific departures from the national unemployment effect. Results are shown in the lower half of Table 4. Weekly hours and real weekly earnings remain strongly procyclical for both timeworkers and pieceworkers and again there are no significant differences in outcomes between these payment methods. However, their degrees of cyclicality are reduced by between $30 \%$ and $50 \%$ compared to their equivalents using national-level unemployment. This direction of finding is not confined to this study. Using the Panel Study of Income Dynamics to estimate real wage cyclicality in the U.S., Devereux (2001) reports that replacing the national unemployment rate with state unemployment rates produces generally lower estimated cyclicality. Real hourly earnings procyclicality for pieceworkers remains robust and compares in magnitude with results using the national-unemployment rate. However, the degree of cyclicality for pieceworkers is now found to be significantly different from that of timeworkers. The latter estimates indicate acyclical hourly earnings for timeworkers when estimated at the local level.

Two results stand out in Table 4. In the first place, real weekly earnings are more procyclical than real hourly earnings. At least in the case of timeworkers we know that the real standard hourly rate of pay was unresponsive to the cycle. This left employers with two alternative ways to adjust their real payroll costs. They could reduce the length of the standard workweek and/or reduce the share of overtime hours within total hours. We further investigate these two mechanisms below. In the second place, the hourly earnings of pieceworkers are more procyclical than their timeworker equivalents in the area-specific regressions. Like timeworkers, 
pieceworkers were paid overtime rates for hours in excess of the maximum 47 hours standard workweek. So, the overtime effect on wage cyclicality applied to both groups. However, we note from expression (2) that a pieceworker's intensive margin pay is conditioned not only by working hours but also by work intensity per period. During economic downturns, pieceworkers' hourly earnings may typically have been reduced by two complementary effects:

first, through a reduced share of premium pay within total hourly pay, and second through lower work effort per period as production throughput decreased. We have no way of verifying the latter influence but it is at least consistent with the observation of greater hourly real earnings procyclicality among pieceworkers.

\section{(b) Composition biases?}

Estimates of wage cyclicality using aggregate data may be downwardly biased due to employment compositional effects. At least in the early stages of the Depression, employers may have reduced disproportionately their stocks of lower skilled and/or less able workers in order to preserve sunk investments in apprenticeship training as well as the general quality of human capital. To the extent that low skilled workers dominated subsequent unemployment numbers, they were likely to have been disproportionately hired during the economic recovery stages. One potentially major curb on such a firing and hiring strategy in inter-war Britain was the fact that the manufacturing workforce was heavily unionized.

The problem of composition bias is dealt with in individual-level panels by differencing wage-unemployment equations in order to control for the first-order effects on wages of such features as an individual's ability, work application, motivation, educational background (Bils, 1985; Solon, Barsky and Parker, 1994). Our most disaggregated units are blue collar 
pieceworkers or timeworkers by occupation and by engineering district. We cannot, therefore, control for personal attributes that may influence firms' decisions on who to dismiss and who to retain during the downturn of the cycle. But we can at least go further than previously possible for this time period. First, our occupational wages are delineated to some considerable degree by skill level, from skilled fitters to laborers. For example, as shown in Table 2, we can differentiate not only between fitters and other core occupations but also between skilled fitters and fitters other than skilled. Second, we are able to distinguish between pieceworkers and timeworkers. As discussed in Section 2 (b), more able workers are likely to self select into piece work perceiving that an incentive compatible payment system is likely better to reward their relative work advantages. Third, educational background did not display wide variations across the blue collar workforce during the 1920s and 1930s, with the large majority of workers receiving only basic school education, leaving school at the minimum age of $14 .{ }^{18}$

While we would expect to find that the wage bias resulting from workforce composition effects would be countercyclical this does not necessarily imply that greater disaggregation would necessarily lead to the observation of greater wage procyclicality. Another form of composition bias, related to firms rather than workers, may run in the opposite direction. So, for example, if high wage firms are more sensitive to fluctuations in the business cycle then this would lead to procyclical biases within industry-level aggregation while firm-level disaggregation may lead to lower procyclicality (Chirinko, 1980; Barsky and Solon, 1989).

\footnotetext{
${ }^{18}$ From the 1979 British Labour Force Survey, we can establish that for those workers under the age of 18 between 1929 and 1937, 65\% left school at age 14, 13\% at age 15 and 5\% at under the age of 14. It is unlikely that manufacturing blue collar workers accounted for more than a small fraction of the remaining $17 \%$.
} 
It is clearly of interest to find out the effects on estimated cyclicality of aggregating our data to the level of the complete EEF company membership. For pieceworkers and timeworkers separately, we constructed aggregate measures of our wage and hours variables by time period, weighting by the number of individuals employed each year. Thus, our complete data far each pay group are reduced to 11 annual observations. Of course, we are limited to using the national unemployment rate to represent the cycle. Taking the real weekly earnings regression for pieceworkers is an example, we have $\Delta \log E_{t}^{P}=c_{0}+c_{1} \Delta U_{t}+c_{2} Y E A R_{t}+\varepsilon_{t}$.

Results are shown in Table 5. In the event, outcomes are in line with the estimates shown in Table 4. Weekly hours and earnings are strongly procyclical, as are the hourly earnings of pieceworkers. These findings are highly reflective of a similar exercise undertaken by Bils (1985) who, when aggregating his real wage data along similar lines, found that his estimates of wage procyclicality remained undiminished. They suggest that compositional biases are probably not strongly influential on findings in the EEF data.

(c) The role of working time and the north-south district dichotomy

There are two hours' effects on pay cyclicality in our data. First, cuts in the length of the standard workweek serve to reduce weekly earnings while leaving average hourly pay unaffected. Second, falls in the share of overtime hours reduce hourly pay because overtime is remunerated at a premium rate. Dividing districts into northern and southern/midland may help cast more insight on these two pay repercussions.

Northern districts, with predominantly traditional engineering and metal working firms suffered larger reductions in standard workweeks in the early years of the Depression resulting in a greater incidence of short-time working. In the southern and midland districts, with activity 
geared far more to modern growth industries, hours reductions were less severe and impacted far more on reduced overtime working. The position is illustrated in Table 6 which shows relative weekly hours reductions in the two districts groups between 1929 and 1932 as well as changes in the share of overtime within total weekly hours. In 1929, timeworkers’ weekly hours in the north, at 48.1, averaged 1.1 hours of overtime. At the same time, the average workweek in the south/midlands was 51.0 hours, representing an average of 4 weekly hours of overtime. By 1932, weekly hours had reduced by $9.1 \%$ among northern timeworkers and represented average short-time working of 3.3 hours. In the south/midlands, weekly hours of timeworkers reduced by $6.5 \%$ leaving average weekly hours above the maximum length of the standard workweek. In terms of the share of overtime, in 1929 northern districts, at 4\%, had half the share of southern/ midland districts. By 1932, overtime had been virtually eliminated in the north but still averaged a 3.3\% share in the south/midlands. Similar, though somewhat less pronounced hours effects are displayed among pieceworkers in Table 6.

Adopting the methodology described in Section 4, estimation was undertaken with respect to these two district groupings. Again, we distinguish between national and district unemployment effects. Results are presented in Table 7. Using the national unemployment rate, there are no significant differences between north and south/midlands outcomes and, moreover, findings remain strongly in line with outcomes in Tables 4 and 5. District-level results produce modifications to earlier findings. First, contrary to northern districts, estimated weekly hours are found to be acyclical in the southern/midland districts. This is reflective of Figure 3 where it is shown that weekly hours in London and Coventry - two of the largest districts in the south and Midlands with high concentrations of modern engineering and metal working activities displayed mild reactions to the cycle and continued to average significant overtime working 
throughout the Depression. In line with the hours regression, estimated procyclicality of real weekly earnings is weaker in the south/midlands than in northern districts. Second, and especially in relation to pieceworking, real hourly earnings procyclicality in southern/midland districts was higher than in the north. This is due to the fact that, in the former districts overtime hours as a share of total hours was more significant and acted more effectively as a pay buffer to downturns in production activity.

\section{Conclusions}

Almost certainly influenced by aggregate observations of the behavior of wage rates during the Great Depression, Keynesian and classical economists argued that we should observe countercyclical wage movements. Since the advent of individual-level panel estimation in the mid 1980s, the strengthening view is that real wages are strongly procyclical. While we cannot match the degree of disaggregation of modern data sets, we have investigated the Great Depression cycle using considerably more disaggregated data than previously employed for this period. At least with respect to blue collar workers employed in the British engineering and metal working industries - which represent the core of British manufacturing activity - we obtain evidence of strong procyclicality of weekly hours and weekly earnings. Hourly real earnings of pieceworkers are also strongly procyclical.

Hours are central to the manufacturing story revealed here. For timeworkers, nominal standard wage rates adjusted downwards in line with price movements leaving the hourly real standard wage to be unresponsive to the cycle. But employers could react to the downturn in economic activity by reducing standard and, in many cases, overtime hours. Unlike real standard wage rates, real weekly earnings were highly procyclical. The fact that hours cutbacks also 
involved reductions in the share of overtime to total hours, especially within the more modern engineering and metal working enterprises, served to increase the potency of hours movements as a means of controlling labor costs. Pieceworkers' work weeks were also considerably shortened. We have no evidence on what happened to piece rate pricing. Unlike, standard wages for timeworkers, piece rates may have reduced in real terms. Almost certainly, however, work effort per hour would have fallen during the depth of the Depression. Some or all of these factors combined to produce strong procyclicality in the real hourly pay of this group of workers. Piece-rated work applied to over 50 percent of the total blue collar workforce in this period and, therefore, constituted an important quantitative feature of overall wage cyclicality in British manufacturing industry. 


\section{References}

Abraham, K.G. and J.C. Haltiwanger. 1995. Real wages and the business cycle. Journal of Economic Literature 33: 1215-1264.

Angrist, J.D. and J-S Pischke. 2009. Mostly harmless econometrics. Princeton: Princeton University Press.

Barsky, R. and G. Solon. 1989. Real wages over the business cycle. NBER Working Paper, No. 2888.

Bernanke, B.S. 1986. Employment, hours, and earnings in the Depression: an analysis of eight manufacturing industries. American Economic Review 76: 82-109.

Bernanke, B.S. and J. Powell. 1986. The cyclical behavior of industrial labor markets: a comparison of the pre-war and post-war eras. In R.J. Gordon, ed., The American business cycle: continuity and change. Chicago: University of Chicago Press.

Bils, Mark J. 1985. Real wages over the business cycle: evidence from panel data. Journal of Political Economy 93, 666-689.

Blanchflower, D.G. and A.J.Oswald, 1994, Estimating the wage curve for Britain, Economic Journal 104, 1025-1043.

Brown, C. 1990. Firms’ choice of method of pay. Industrial and Labor Relations Review 43, 165-S-182-S.

Carlin, W and D Soskice. 1990. Macroeconomics and the wage bargain. Oxford: Oxford University Press.

Chapman, A.L. 1952, Wages and salaries in the UK, 1920-38, Cambridge, Cambridge University Press.

Chirinko, R.S. 1980. The real wage rate over the business cycle. Review of Economics and Statistics 62, 459-461. 
Devereux, Paul J. 2001. The cyclicality of real wages within employer-employee matches. Industrial and Labor Relations Review 54, 835-850.

Feinstein, C.H. 1972. National income, expenditure and output of the United Kingdom 18551965, Cambridge, Cambridge University Press.

Hart, R.A. 2008. Piece work pay and hourly pay over the cycle. Labour Economics 15, 1006-1022.

Hart, R.A. and D.I. MacKay. 1975. Engineering earnings in Britain, 1926-1938. Journal of the Royal Statistical Society (Series A) 138, 32-50.

Hill, T. P. and K.G.J.C. Knowles. 1956. The variability of engineering earnings, Bulletin of the Oxford University Institute of Statistics 18, 97-139.

Knowles, K.G.J.C. and Hill, T. P. 1954. The structure of engineering earnings. Bulletin of the Oxford University Institute of Statistics 16, 272-328.

Lazear, E.P. 1986. Salaries and piece rates. Journal of Business 59, 405-431.

Ministry of Labour. 1928. Report of an Enquiry into Apprenticeship and Training, 1925-1926. VII- General Report. London: HMSO

Moulton, Brent R. 1986. Random group effects and the precision of regression estimates. Journal of Econometrics 32, 385-397.

Pencavel, J. 1977. Work effort, on-the-job screening, and alternative methods of remuneration, Research in Labor Economics 1, 225-258.

Oi, W. 1962. Labor as a quasi-fixed factor. Journal of Political Economy 70, 538-555.

Pissarides, C.A. 2009. The unemployment volatility puzzle: is wage stickiness the answer? Econometrica 77, 1339-1369.

Seiler, E., 1984, Piece rate vs. time rate: the effect of incentives on earnings, The Review of Economics and Statistics, 66 363-376. 
Solon, Gary, Robert B. Barsky, and Jonathan A. Parker. 1994. Measuring the cyclicality of real wages: how important is composition bias? Quarterly Journal of Economics 109, 1-26.

Swanson, E.T. 2007. Real wage cyclicality in the Panel Study of Income Dynamics. Scottish Journal of Political Economy 54, 617-47.

Wigham, E. 1973. The power to manage. A history of the Engineering Employers' Federation. London: Macmillan. 


\section{Appendix: Wages, Hours and the Cycle}

Within a very simple framework, we bring together here the key variables and concepts. Thus, we consider a representative firm that employs two homogeneous groups of workers. Group 1 consists of skilled and productive workers and group 2 comprises less skilled and less productive workers. All workers are time rated. At time $t$, each worker in group 1 is paid a standard hourly wage, $w_{1 t}$ and each worker in group 2 receives $w_{2 t}$. The skill differential is reflected by $w_{1 t}>w_{2 t}$.

(A) Wages, hours, and workforce composition bias.

For simplicity, let all workers work the same total hours and the same length of weekly overtime. Each worker's total weekly hours of work, $h_{t}$, are divided into two parts, or

(i) $h_{t}=h s_{t}+\left(h_{t}-h s_{t}\right)$

where $h s_{t}$ represents standard, or straight time, weekly hours and where $\left(h_{t}-h s_{t}\right) \geq 0$ represents overtime hours. Further, all workers receive compensation for each hour of overtime at a constant mark-up, $k(k \geq 1)$. In fact, this is a simplification that closely approximates the system of overtime remuneration across EEF firms.

Each skill group's geometric mean hourly wage rate is

(ii) $\hat{w}_{j t}=\left(w_{j t}\right)^{\lambda_{t}}\left(k \cdot w_{j t}\right)^{1-\lambda_{t}} \quad(j=1,2)$

where $\lambda_{t}=h s_{t} / h_{t}$. Then, taking logs, we have

(iii) $\log \hat{w}_{j t}=\log w_{j t}+\left(1-\lambda_{t}\right) \ln k$. 
The geometric mean weekly earnings across all workers in the firm is

(iv) $E_{t}=\left(\hat{w}_{1 t}\right)^{\gamma_{t}}\left(\hat{w}_{2 t}\right)^{1-\gamma_{t}} \cdot h_{t}$

where $\gamma_{t}=H_{1 t} / H_{t}$, or group 1's share of total payroll hours (i.e. $H_{\mathrm{t}}=\Sigma h_{t}$ over all workers and $H_{1 t}$ $\left.=\Sigma h_{1 t}\right)$. Hence

(v) $\log E_{t}=\log \hat{w}_{2 t}+\gamma_{t}\left(\log \hat{w}_{1 t}-\log \hat{w}_{2 t}\right)+\log h_{t}$

Let the state of the business cycle at time $t$, be represented by the national unemployment rate, $U_{t}$. Substituting (iii) into $(v)$ and differentiating with respect to $U_{t}$ we have

(vi) $\frac{d \log E_{t}}{d U_{t}}=\frac{d \log w_{1 t}}{d U_{t}}\left(\gamma_{t}\right)+\frac{d \log w_{2 t}}{d U_{t}}\left(1-\gamma_{t}\right)+\frac{d \log \gamma_{t}}{d U_{t}}\left(\log w_{1 t}-\log w_{2 t}\right)+\frac{d \log h s_{t}}{d U_{t}}-\frac{d \lambda_{t}}{d U_{t}}(\log k)$.

In the context of the Great Depression years, it is difficult to take a strong a priori view concerning the cyclicality of standard wages - i.e. $d \log w_{j t} / d U_{t}(j=1,2)$. By contrast, we would expect that $d \log _{t} / d U_{t}>0$ or that the share of skilled to total workers would be countercyclical. The last expression in (vi) would be expected to be procyclical or $d \lambda_{t} / d U_{t}<0$ : the share of overtime to total hours varies positively with the cycle. As for the penultimate expression, we would anticipate that it is either procyclical or acyclical, i.e. $d \log h s_{t} / d U_{t} \leq 0$. For mild recessions, overtime hours may act as a buffer that soaks up the fluctuations in business activity leaving standard hours constant. In more severe recessionary periods - and certainly during the Great Depression- standard hours would themselves reduce as short time working schedules are introduced. 
We can easily adjust the set-up here to reflect differential overtime hours between group 1 and group 2 workers. Outcomes would be expected to be conditioned by the degree of complementarity between skilled and unskilled workers. If group 1 workers undertake longer overtime hours than group 2, for example, then we may observe both extensive and intensive margin compositional bias effects. As business activity declines group 1's share of the total payroll may rise due to (a) a higher propensity to layoff group 2 workers, and (b) group 1's increased relative share of overtime hours paid for at a premium rate.

\section{(ii) Paid-for and effective hours}

So far we have assumed that there is no slack time. What if we were to introduce the notion that worsening business activity may result in a divergence between paid-for hours and effective hours? The best known motivation of such an outcome is the labor hoarding hypothesis (Oi, 1962). Firms may be prepared to allow underutilisation of labor inputs, at least in the short-run, if they calculate that the marginal costs associated with falls in hourly productivity are less than the anticipated marginal costs of losses of human capital due to separation Suppose that, for this type of reason, the industry is risk averse about losing skilled workers. By contrast, and for simplicity, it is assumed that the firm does not allow reductions in hourly productivity among less skilled workers because separation costs in this case are perceived to be relatively low.

Again, we concentrate on time rated workers. Since overtime working and labor hoarding are unlikely to occur contemporaneously, we assume $\left(h_{t}-h s_{t}\right)=0$ in (i) and so $h s_{t}=h_{t}$. Let $h_{1 t} \geq h_{1 t}^{e}$ where $h_{1 t}^{e}$ is effective hours worked of skilled workers and $h_{1 t}$ is actual, or paid-for, hours. 
The mean hourly wage rate of the skilled group is

(vii)

$$
\tilde{w}_{1 t}=\left(w_{1 t}\right)^{\theta_{t}}\left(\alpha \cdot w_{1 t}\right)^{1-\theta_{t}} \quad(\alpha \leq 1)
$$

where $\theta_{t}=h_{1 t}^{e} / h_{1 t} \leq 1$ and the constant $\alpha$ recognises that unproductive hours may be remunerated at less than the standard hourly wage rate.

Re-expressing (vii) in logs:

(viii) $\log \tilde{w}_{1 t}=\log w_{1 t}+\left(1-\theta_{t}\right) \log \alpha$

Average weekly earnings across both work groups are given by

(ix) $E_{t}=\left(\tilde{w}_{1 t}\right)^{\gamma_{t}}\left(w_{2 t}\right)^{1-\gamma_{t}} \cdot h_{t} \cdot{ }^{19}$

Logging (ix) and using (viii) gives

(x) $\log E_{t}=\gamma_{t} \log w_{1 t}+\left(1-\gamma_{t}\right) \log w_{2 t}+\gamma_{t}\left(1-\theta_{t}\right) \log \alpha+\log h_{t}$.

Differentiating (x) by $U_{t}$ produces

$$
\begin{aligned}
& \text { (xi) } \frac{d \log E_{t}}{d U_{t}}=\frac{d \log w_{1 t}}{d U_{t}}\left(\gamma_{t}\right)+\frac{d \log w_{2 t}}{d U_{t}}\left(1-\gamma_{t}\right)+\frac{d \log \gamma_{t}}{d U_{t}}\left\{\left(\log w_{1 t}-\log w_{2 t}\right)+\left[\left(1-\theta_{t}\right) \log \alpha\right]\right\} \\
& -\frac{d \log \theta_{t}}{d U_{t}}\left(\gamma_{t} \cdot \log \alpha\right)+\frac{d \log h_{t}}{d U_{t}}
\end{aligned}
$$

The key outcome is that, compared to expression (iv), allowing skilled paid for hours to diverge from effective hours adds to the problem of composition bias. First, and recalling that $d \gamma_{t} / d U_{t}>0$, the bias is now reflected not only through $w_{1 t}>w_{2 t}$ but also by the term $\left[\left(1-\theta_{t}\right) \log \alpha\right]$

\footnotetext{
${ }^{19}$ We again use $\gamma_{t}$ to represent group 1's share of total payroll hours though we note that group 1 's hours comprise the additon of effective and hoarded hours.
} 
$\geq 0$, which represents payment to skilled workers during slack time. Second, - $d \theta_{t} / d U_{t} \geq 0$ represents a countercyclical hours' effect on earnings; the proportion of slack to total hours increases during a downturn. In summary, a rise in unemployment may associate on the intensive margin with increases in (a) the skilled wage above its effective rate and (b) skilled workers' share of total hours through the creation of a positive gap between paid-for and effective hours. 


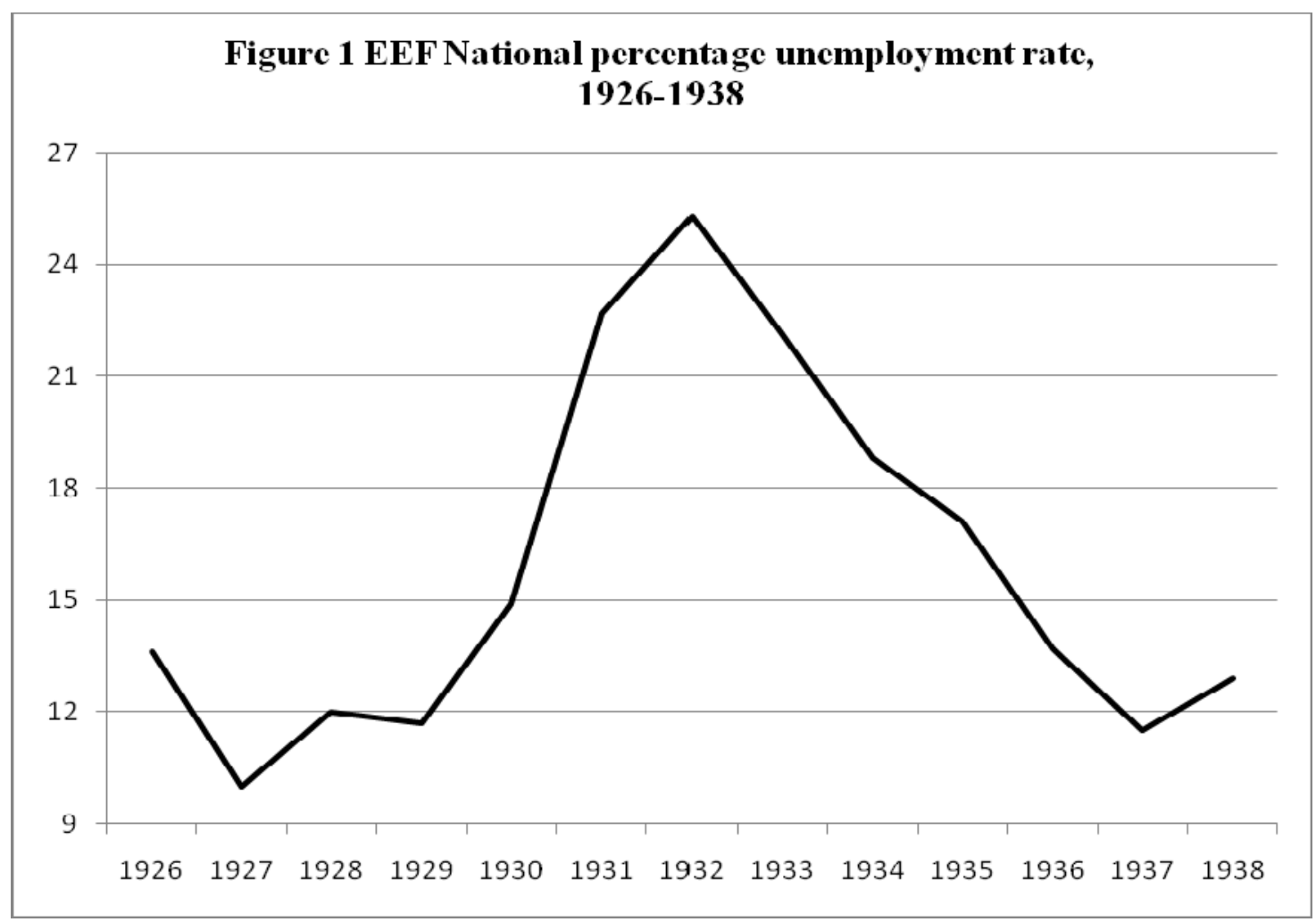

Figure 2 The relative importance of the British engineering industry and EEF member companies within total manufacturing, 1927-1935

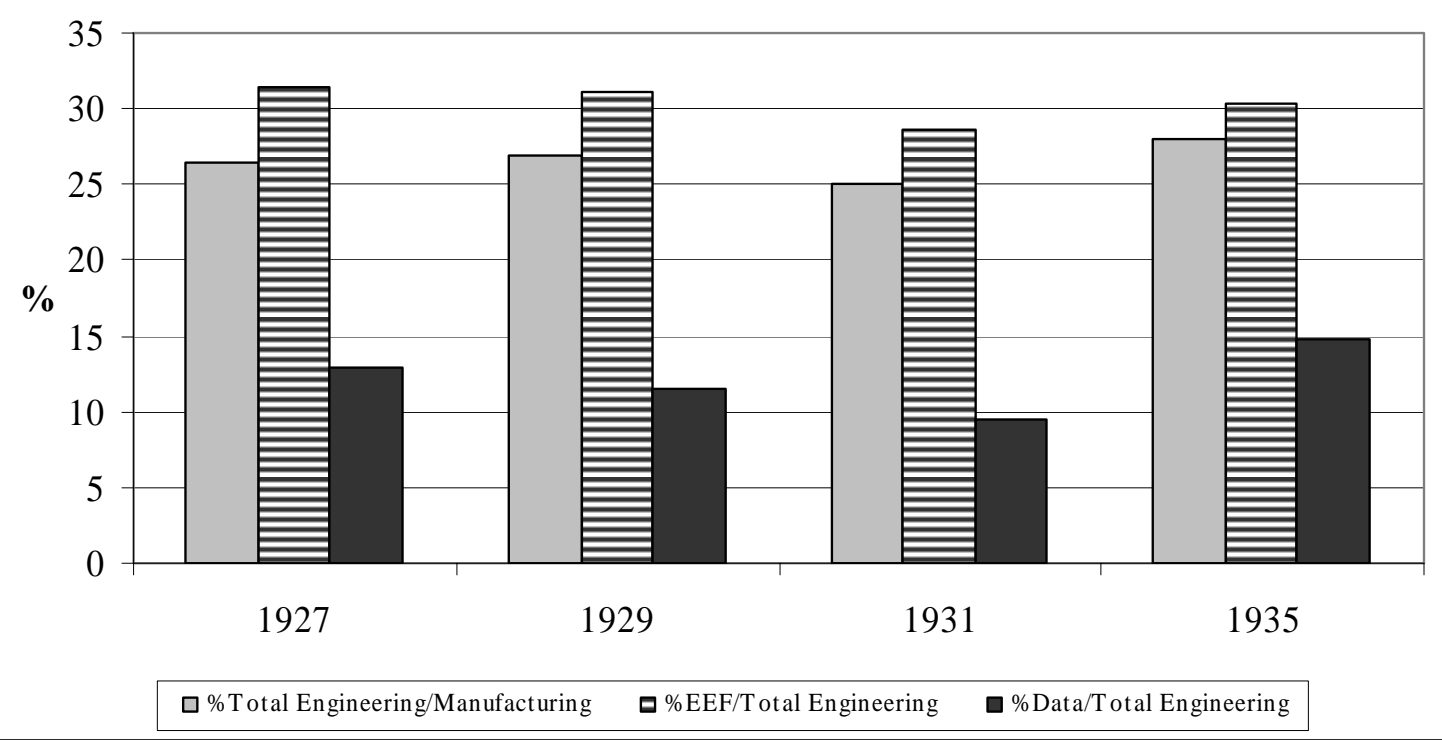




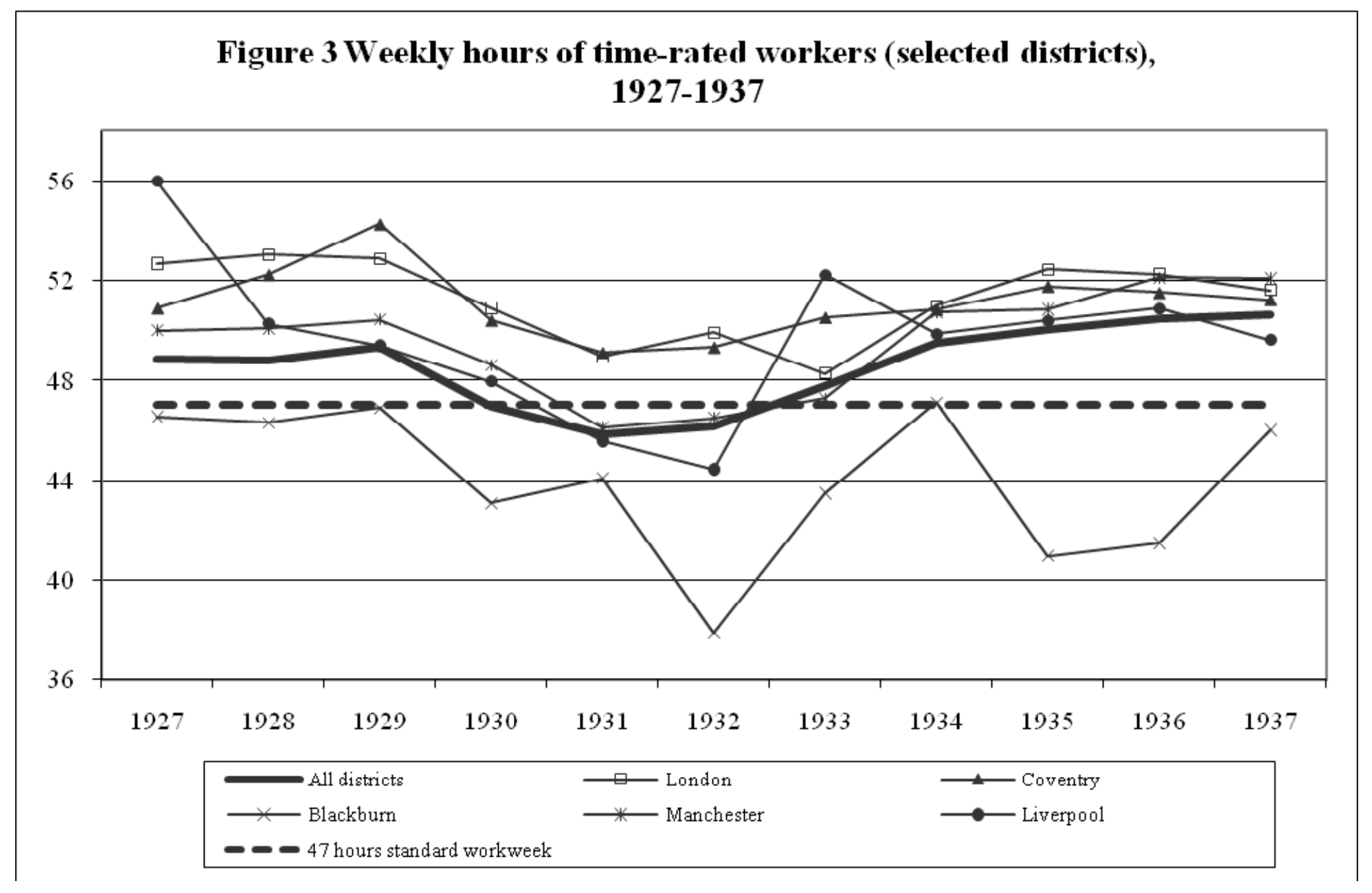




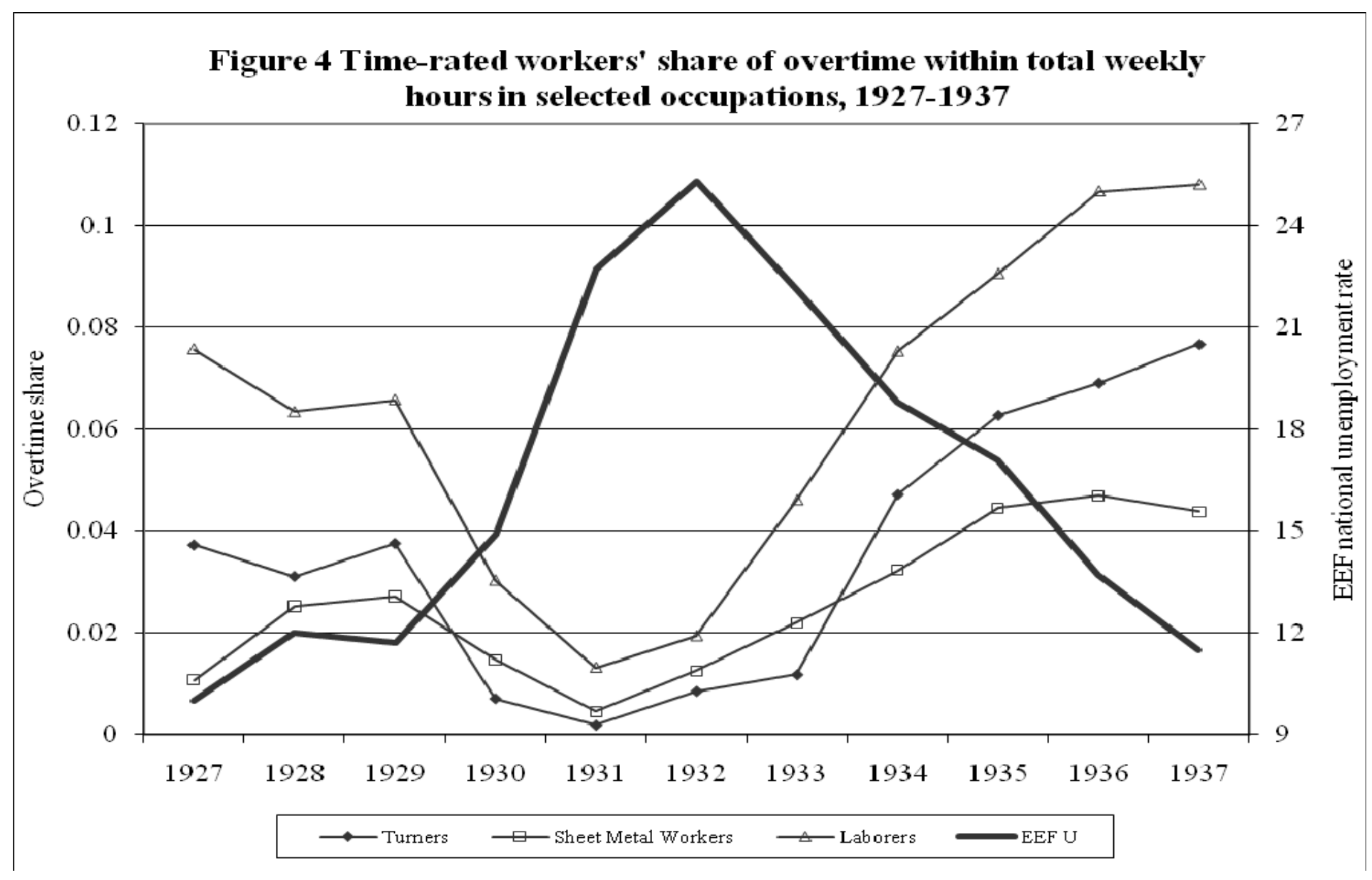


Figure 5 Aggregate hours, prices, wages, and unemployment, 1927-1937 [timeworkers = t/w; pieceworkers = p/w]

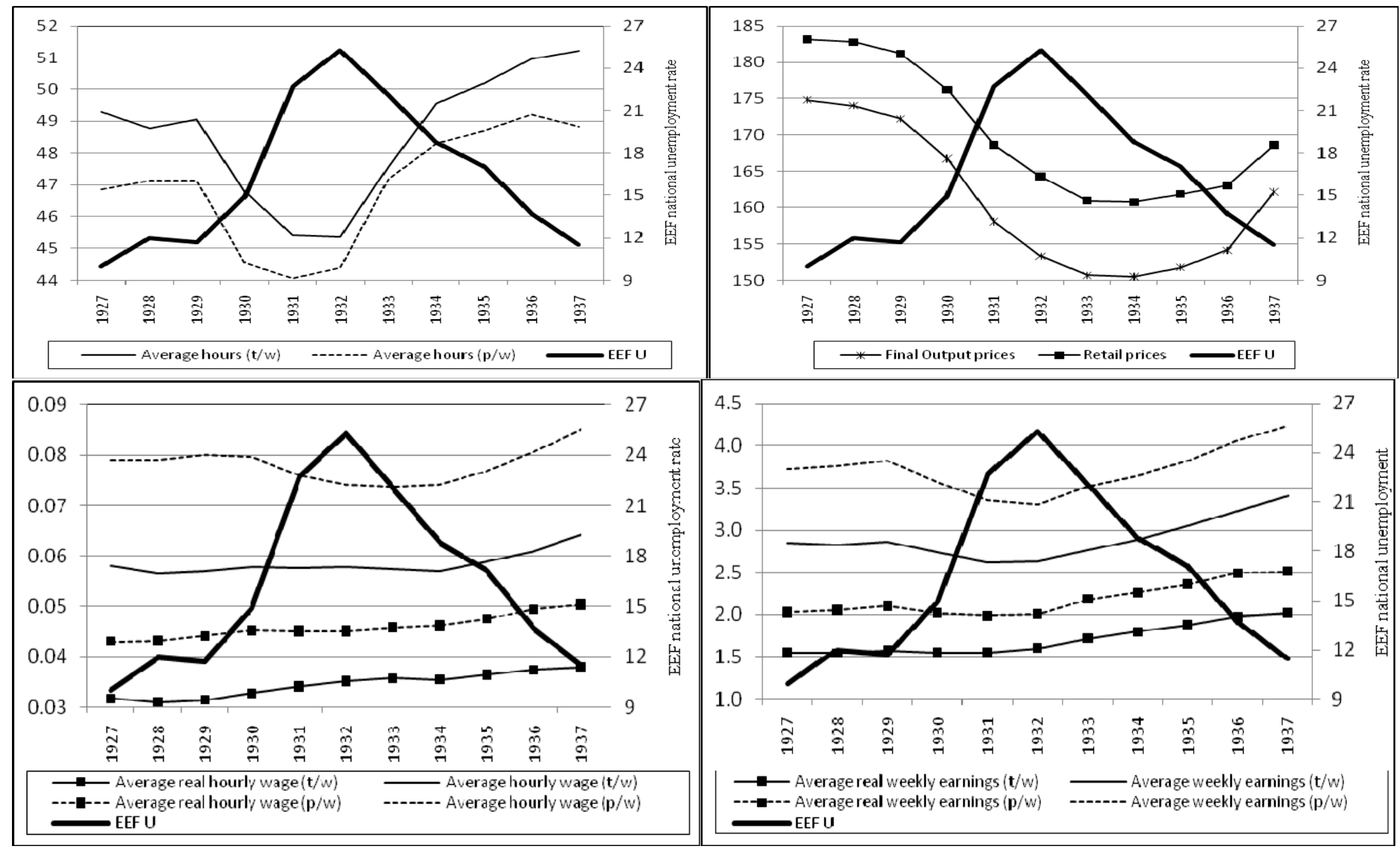


Figure 6 Weekly earnings differential of pieceworkers and timeworkers , $1927-1937$
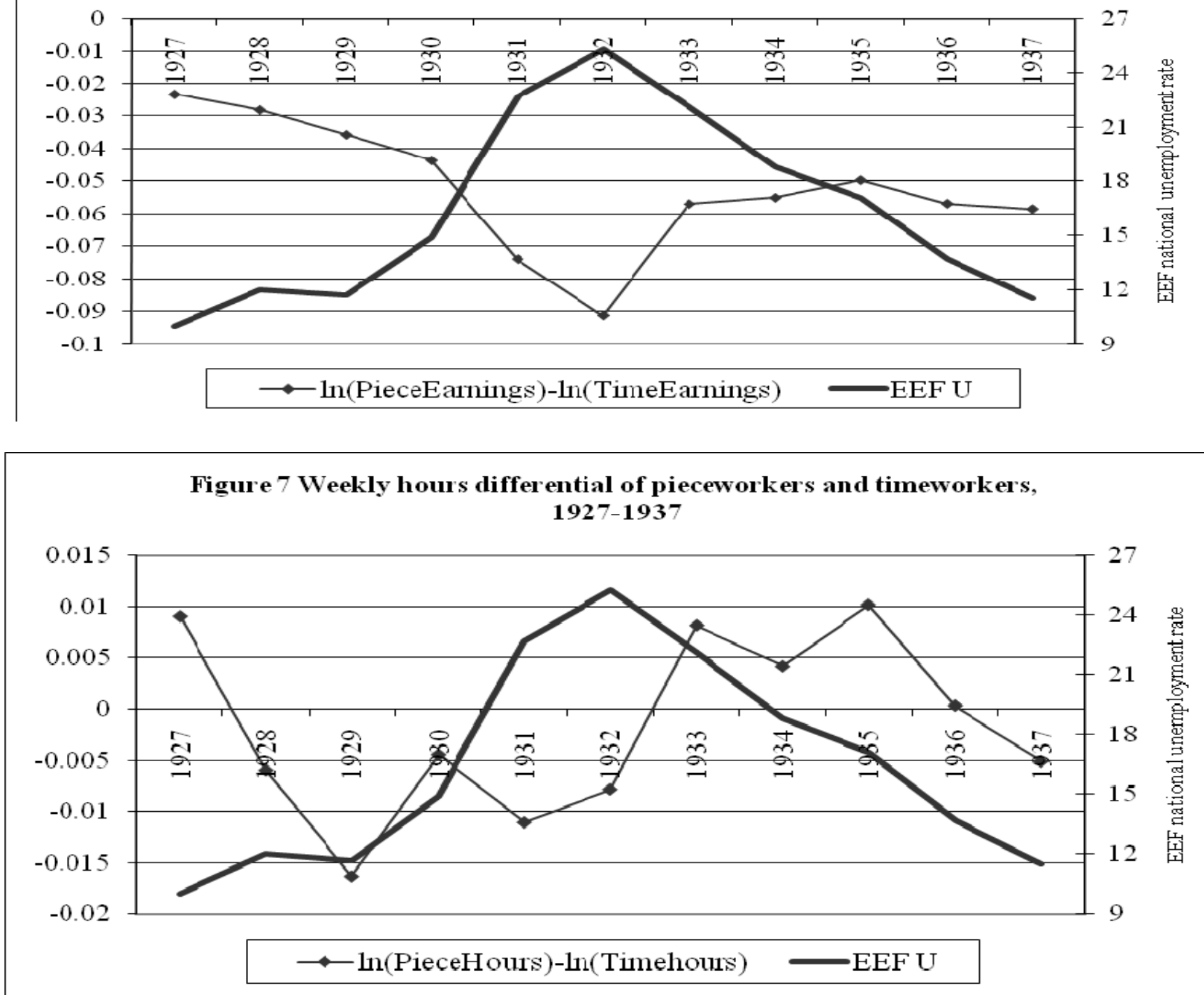


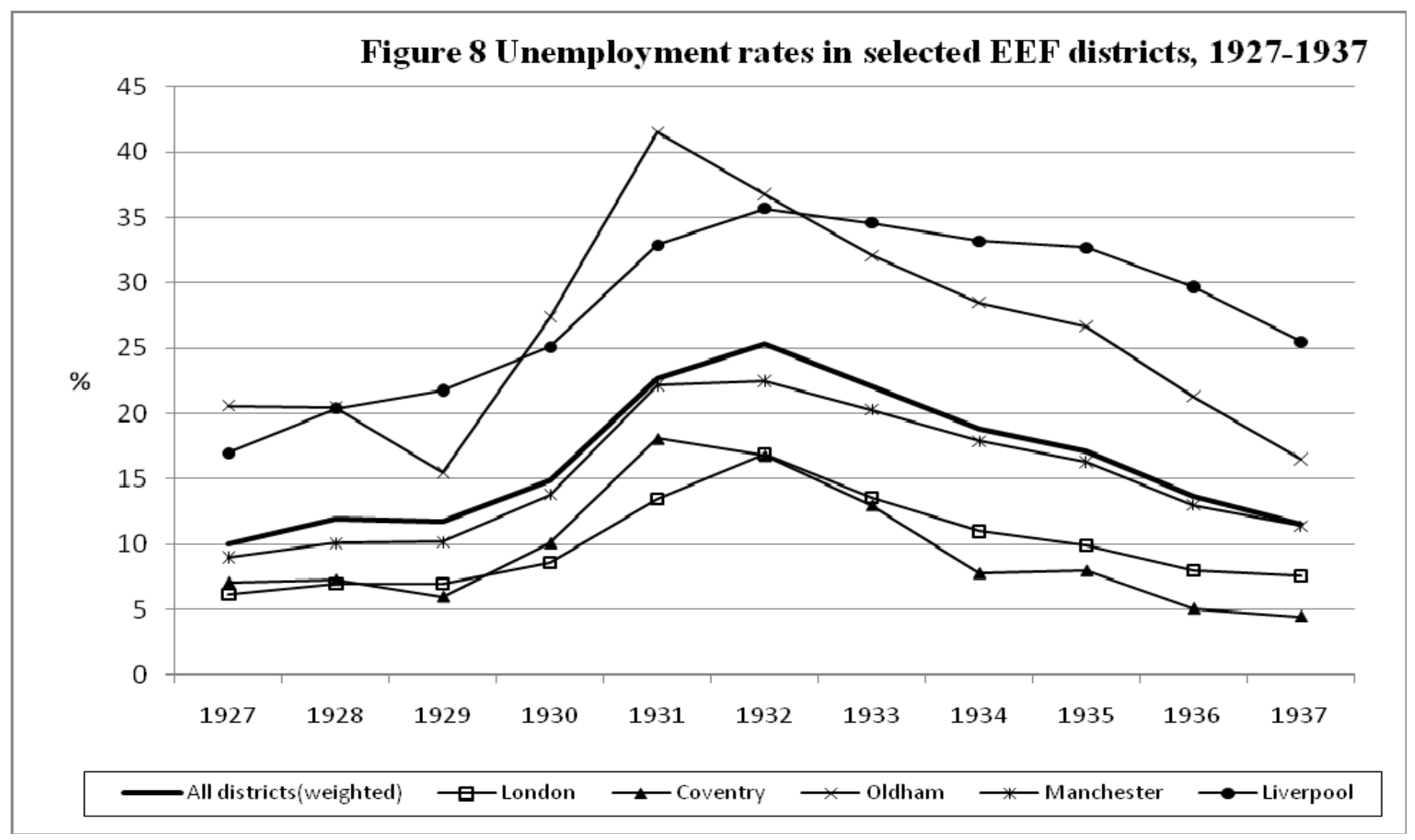


Table 1 Industries, Occupations, Engineering Sections and Engineering Districts covered in the Inter-War EEF Payroll Data

\begin{tabular}{|c|c|}
\hline $\begin{array}{l}\text { Industries covered by } \\
\text { EEF membership } \\
\text { (Using Ministry of } \\
\text { Labour classifications) }\end{array}$ & $\begin{array}{l}\text { Heating and Ventilation Apparatus; Scientific \& Photography; Motor Vehicles, Cycles \& Aircraft; Metal; Industries not separately } \\
\text { specified; Constructional Engineering; Iron \& Steel Tubes; Stove, Grate, Pipe etc \& general Iron Founding; Explosives; Hand Tools, } \\
\text { Cutlery, Saws, Files; Marine Engineering; Brass, Copper, Zinc, Tin, Lead etc.; General Engineering; Brass and Allied Metal Wares; } \\
\text { Watches, Clocks, Plate, Jewellery etc.; Wire, Wire Netting, Wire Ropes; Steel Melting \& Iron Puddling, Iron \& Steel Rolling and } \\
\text { Forging; Bolts, Nuts, Screws, Rivets, Nails etc.; Tin Plate; Carriages , carts etc. }\end{array}$ \\
\hline Occupations & $\begin{array}{l}\text { Coppersmiths; Fitters; Fitters (other than skilled); Fitters (skilled); Toolroom Fitters; Machinemen (rated at or above fitter's rate); } \\
\text { Machinemen (rated below a fitter's rate); Moulders; Moulders (loose pattern); Patternmakers; Platers/Riveters/Caulkers; Sheet Metal } \\
\text { Workers; Turners; Laborers. }\end{array}$ \\
\hline Engineering Sections & $\begin{array}{l}\text { Agricultural engineering; Aircraft manufacture; Allied trades; Boilermakers; Brassfounders; Construction engineering; } \\
\text { Coppersmiths; Drop forgers; Electrical engineering; Founders; Gas meter makers; General engineering (heavy); General engineering } \\
\text { (light); Instrument makers; Lamp manufacture; Lift manufacture; Locomotive manufacture; Machine tool makers; Marine } \\
\text { engineering; Miscellaneous; Motors: cars, cycles etc.; Motors (commercial); Scale, beam etc. makers; Sheet metal workers; Tank and } \\
\text { gasholder makers; Telephone manufacture; Textile machinery makers; Vehicle builders. }\end{array}$ \\
\hline Engineering Districts § & $\begin{array}{l}\text { Aberdeen; Barrow; Bedford*; Belfast Marine; Birkenhead; Birmingham*, Blackburn; Bolton; Border Counties; Bradford; } \\
\text { Burnley; Burton*, Coventry*; Derby*; Doncaster; Dundee; East Anglia; East Scotland; Grantham; Halifax; Heavy Woollen; } \\
\text { Huddersfield; Hull; Keighly; Kilmarnock; Leeds; Leicester*; Lincoln*; Liverpool; London; Manchester; North East Coast; } \\
\text { Northern Ireland; North Staff**, North West Scotland, Nottingham*; Oldham; Otley; Outer London; Peterborough; Preston; } \\
\text { Rochdale; St Helens; Sheffield; Shropshire; Wakefield; West of England*; Wigan. }\end{array}$ \\
\hline
\end{tabular}

Note: $§$ Bold face denotes districts for which we have matching unemployment rates, of which * denotes belonging to the south or the midlands and the remainder belonging to northern districts. 
Table 2 Summary statistics of EEF payroll data

\begin{tabular}{|c|c|c|c|c|c|c|}
\hline & \multicolumn{2}{|c|}{$1927-1937$} & \multicolumn{2}{|c|}{$1930-1933$} & \multicolumn{2}{|c|}{$1934-1937$} \\
\hline & Piecework & Timework & Piecework & Timework & Piecework & Timework \\
\hline $\begin{array}{l}\text { Mean number of workers per district (standard } \\
\text { deviation) }\end{array}$ & $\begin{array}{c}357 \\
(605)\end{array}$ & $\begin{array}{c}316 \\
(671)\end{array}$ & $\begin{array}{c}265 \\
(510)\end{array}$ & $\begin{array}{c}251 \\
(509)\end{array}$ & $\begin{array}{c}402 \\
(690)\end{array}$ & $\begin{array}{c}297 \\
(675)\end{array}$ \\
\hline Percentage pieceworkers to total workers & \multicolumn{2}{|c|}{53} & \multicolumn{2}{|c|}{51} & \multicolumn{2}{|c|}{57} \\
\hline $\begin{array}{l}\text { Mean percentage difference in piecework and } \\
\text { timework average hourly earnings }\end{array}$ & \multicolumn{2}{|c|}{24.9} & \multicolumn{2}{|c|}{23.7} & \multicolumn{2}{|c|}{23.0} \\
\hline Average total weekly hours & $\begin{array}{l}47.5 \\
(3.6)\end{array}$ & $\begin{array}{l}49.1 \\
(3.8)\end{array}$ & $\begin{array}{l}45.2 \\
(3.7)\end{array}$ & $\begin{array}{l}46.5 \\
(3.7)\end{array}$ & $\begin{array}{l}48.8 \\
(3.8)\end{array}$ & $\begin{array}{l}50.7 \\
(2.8)\end{array}$ \\
\hline Average weekly overtime hours & $\begin{array}{c}1.5 \\
(1.8)\end{array}$ & $\begin{array}{c}2.8 \\
(2.4)\end{array}$ & $\begin{array}{c}0.5 \\
(1.2)\end{array}$ & $\begin{array}{c}1.0 \\
(1.6)\end{array}$ & $\begin{array}{c}2.2 \\
(1.8)\end{array}$ & $\begin{array}{c}3.9 \\
(2.3)\end{array}$ \\
\hline Mean $\Delta \log$ (weekly hours) & $\begin{array}{c}0.6 \\
(7.1)\end{array}$ & $\begin{array}{c}0.9 \\
(8.6)\end{array}$ & $\begin{array}{c}0.2 \\
(9.3)\end{array}$ & $\begin{array}{l}-0.8 \\
(8.1)\end{array}$ & $\begin{array}{c}0.4 \\
(5.5)\end{array}$ & $\begin{array}{c}1.5 \\
(4.3)\end{array}$ \\
\hline Mean $\Delta$ log (real weekly earnings) & $\begin{array}{c}3.1 \\
(8.3)\end{array}$ & $\begin{array}{c}3.7 \\
(7.1)\end{array}$ & $\begin{array}{c}1.8 \\
(10.2)\end{array}$ & $\begin{array}{c}1.5 \\
(8.5)\end{array}$ & $\begin{array}{c}3.7 \\
(7.2)\end{array}$ & $\begin{array}{c}4.5 \\
(4.9)\end{array}$ \\
\hline
\end{tabular}


Table 3 Means (coefficients of variation) of timeworkers' real standard hourly wages and weekly hours by districts, occupations and sections: 1930-1933 and 1934-1937

\begin{tabular}{|c|c|c|c|c|c|c|}
\hline & \multicolumn{2}{|c|}{$\begin{array}{l}\text { Real standard wage 1930- } \\
1933 \text { in pence per hour }\end{array}$} & \multirow{2}{*}{$\begin{array}{l}\text { Percentage } \\
\text { change in real } \\
\text { standard } \\
\text { wage }\end{array}$} & \multicolumn{2}{|c|}{ Weekly hours } & \multirow{2}{*}{$\begin{array}{c}\text { Percentage } \\
\text { change in } \\
\text { weekly } \\
\text { hours }\end{array}$} \\
\hline & 1930-1933 & 1934-1937 & & 1930-1933 & $1934-1937$ & \\
\hline \multicolumn{7}{|l|}{ DISTRICTS } \\
\hline Coventry & $3.61(0.28)$ & $4.03(0.24)$ & 11.63 & $49.79(0.02)$ & $51.26(0.04)$ & 2.95 \\
\hline Halifax & $3.45(0.13)$ & $3.61(0.13)$ & 4.64 & $44.19(0.05)$ & $51.27(0.06)$ & 16.02 \\
\hline Manchester & $3.27(0.19)$ & $3.47(0.18)$ & 6.12 & $47.17(0.03)$ & $51.49(0.03)$ & 9.16 \\
\hline North East Coast & $3.52(0.14)$ & $3.77(0.14)$ & 7.10 & $46.79(0.04)$ & $50.86(0.04)$ & 8.70 \\
\hline Sheffield & $3.39(0.17)$ & $3.58(0.16)$ & 5.60 & $46.91(0.05)$ & $53.88(0.05)$ & 14.86 \\
\hline West Midlands & $3.29(0.18)$ & $3.53(0.18)$ & 7.29 & $48.54(0.05)$ & $51.85(0.02)$ & 6.82 \\
\hline \multicolumn{7}{|l|}{ OCCUPATIONS } \\
\hline Turners & $3.91(0.07)$ & $4.21(0.07)$ & 7.67 & $44.21(0.10)$ & $49.78(0.05)$ & 12.60 \\
\hline Patternmarkers & $4.16(0.07)$ & $4.46(0.06)$ & 7.21 & $45.05(0.06)$ & $48.24(0.04)$ & 7.08 \\
\hline Platers, riveters, caulkers & $3.98(0.09)$ & $4.29(0.09)$ & 7.79 & $45.13(0.08)$ & $48.55(0.07)$ & 7.58 \\
\hline Sheet metal workers & $4.17(0.12)$ & $4.39(0.09)$ & 5.28 & $45.08(0.09)$ & $48.67(0.06)$ & 7.96 \\
\hline Laborers & $2.81(0.05)$ & $3.07(0.06)$ & 9.25 & $47.38(0.07)$ & $51.69(0.03)$ & 9.10 \\
\hline \multicolumn{7}{|l|}{ SECTIONS } \\
\hline Aircraft manufacture & $3.70(0.17)$ & $3.86(0.19)$ & 4.32 & $49.77(0.05)$ & $52.34(0.04)$ & 5.16 \\
\hline $\begin{array}{l}\text { General Engineering } \\
\text { (Heavy) }\end{array}$ & $3.32(0.17)$ & $3.53(0.16)$ & 6.33 & $46.84(0.05)$ & $52.37(0.04)$ & 11.81 \\
\hline $\begin{array}{l}\text { General Engineering } \\
\text { (Light) }\end{array}$ & $3.51(0.15)$ & $3.72(0.15)$ & 5.98 & $45.96(0.04)$ & $50.53(0.03)$ & 9.94 \\
\hline Marine Engineering & $3.55(0.15)$ & $3.89(0.14)$ & 9.58 & $46.19(0.04)$ & $49.08(0.02)$ & 6.26 \\
\hline Motors, cars, cycles & $3.40(0.20)$ & $3.95(0.23)$ & 16.18 & $51.73(0.08)$ & $51.70(0.03)$ & -0.06 \\
\hline $\begin{array}{l}\text { Textile machine } \\
\text { manufacture }\end{array}$ & $3.29(0.17)$ & $3.61(0.15)$ & 9.73 & $39.86(0.09)$ & $45.24(0.03)$ & 13.50 \\
\hline
\end{tabular}


Table 4 Real pay cyclicality of timeworkers and pieceworkers by EEF districts, 1927-1937

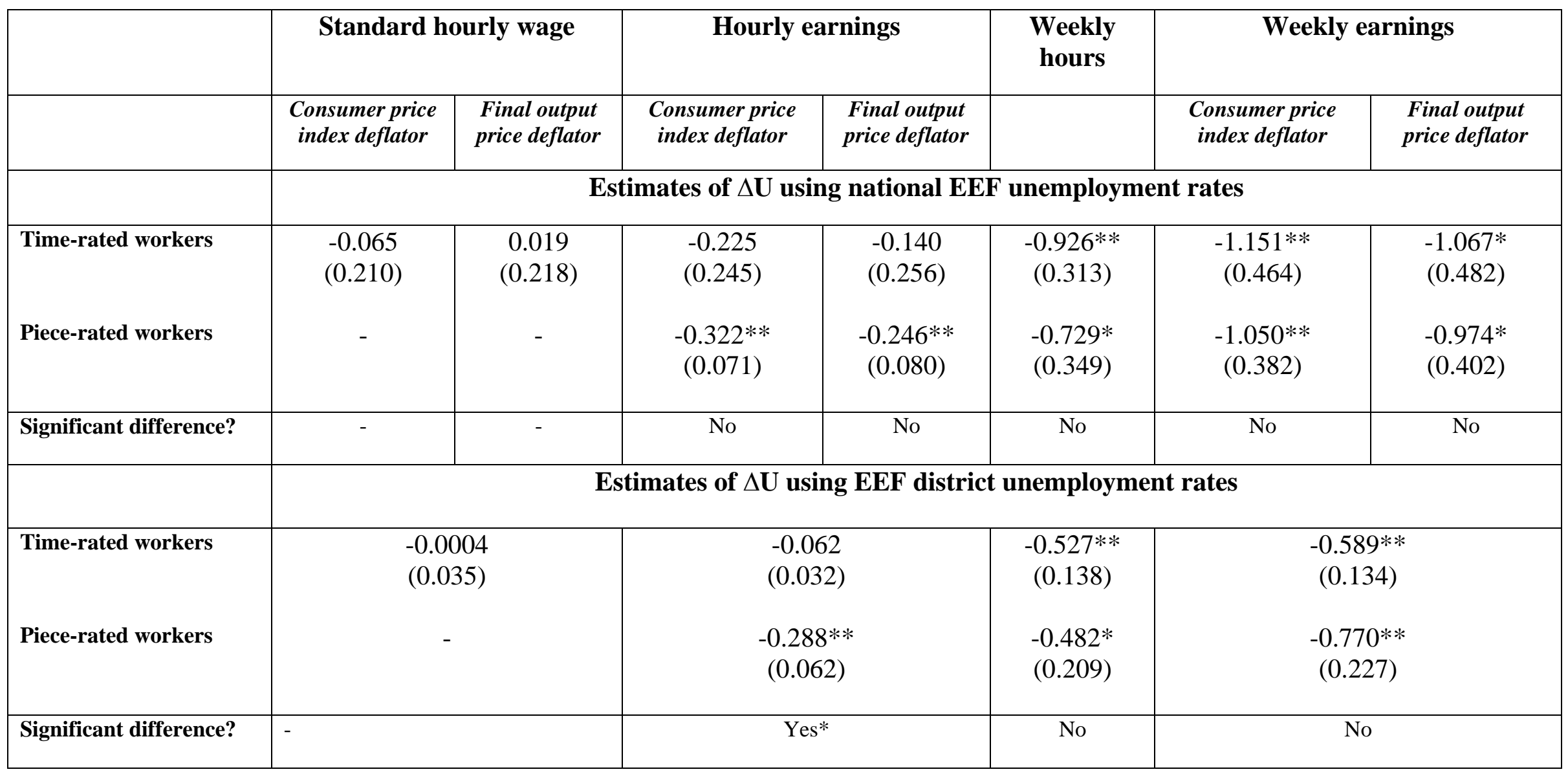

Notes: Robust standard errors in brackets with ${ }^{* *}(*)$ indicating $0.001(0.005)$ significance on two-tail test. Price deflators are obtained from Feinstein (1972, Table 61). Using national unemployment, there are 4286 total workers in step 1 estimation and 11 observations in step 2 (i.e. 4286, 11). The equivalent numbers for timeworkers are $(2410,11)$ and for pieceworkers 2410,11$)$. Using district unemployment rates, there are (3589, 305) observations for total workers, $(1876,305)$ timeworkers, and $(1713,285)$ pieceworkers. 
Table 5 Real pay cyclicality based on aggregated EEF data, 1927-1937

\begin{tabular}{|c|c|c|c|c|c|c|c|}
\hline & \multicolumn{2}{|c|}{ Standard hourly wage } & \multicolumn{2}{|c|}{ Hourly earnings } & \multirow{2}{*}{$\begin{array}{l}\text { Weekly } \\
\text { hours }\end{array}$} & \multicolumn{2}{|c|}{ Weekly earnings } \\
\hline & $\begin{array}{l}\text { Consumer price } \\
\text { index deflator }\end{array}$ & $\begin{array}{l}\text { Final output } \\
\text { price deflator }\end{array}$ & $\begin{array}{l}\text { Consumer price } \\
\text { index deflator }\end{array}$ & $\begin{array}{l}\text { Final output } \\
\text { price deflator }\end{array}$ & & $\begin{array}{l}\text { Consumer price } \\
\text { index deflator }\end{array}$ & $\begin{array}{l}\text { Final output } \\
\text { price deflator }\end{array}$ \\
\hline Time-rated workers & $\begin{array}{l}-0.180 \\
(0.357)\end{array}$ & $\begin{array}{l}-0.097 \\
(0.366)\end{array}$ & $\begin{array}{l}-0.389 \\
(0.397)\end{array}$ & $\begin{array}{l}-0.306 \\
(0.408)\end{array}$ & $\begin{array}{c}-0.786 * * \\
(0.204)\end{array}$ & $\begin{array}{c}-0.957 * * \\
(0.365)\end{array}$ & $\begin{array}{l}-0.874^{*} \\
(0.382)\end{array}$ \\
\hline Piece-rated workers & - & - & $\begin{array}{c}-0.342 * * \\
(0.081)\end{array}$ & $\begin{array}{c}-0.265^{* *} \\
(0.080)\end{array}$ & $\begin{array}{l}-0.566 * \\
(0.258)\end{array}$ & $\begin{array}{c}-0.891^{* *} \\
(0.245)\end{array}$ & $\begin{array}{c}-0.814^{* *} \\
(0.264)\end{array}$ \\
\hline Significant difference? & - & - & No & No & No & No & No \\
\hline
\end{tabular}

Notes: Robust standard errors in brackets with ** (*) indicating 0.001(0.005) significance on two-tail test. Price deflators are obtained from Feinstein (1972, Table 61). Wages and hours data are disaggregated to national annual observations and the national unemployment rates shown in Table 1 measure the cycle. There are 11 observations in each regression and OLS estimates are weighted by numbers of workers in each year. 
Table 6 Weekly hours and overtime shares by northern and sourthern/midland districts: 1929 and 1932

\begin{tabular}{|l||c|c|c||c|c|c||}
\hline \multicolumn{1}{||}{} & \multicolumn{3}{||}{ TIMEWORKERS } & \multicolumn{2}{c||}{ PIECEWORKERS } \\
\hline & 1929 & 1932 & \% Change & 1929 & \\
\hline WEEKLY HOURS & & & & & \\
\hline Northern Districts & 48.1 & 43.7 & -9.1 & 46.3 & 43.0 & -7.1 \\
\hline South/Midland Districts & 51.0 & 47.7 & -6.5 & 48.0 & 45.6 & -5.0 \\
\hline SHARE OF OVERTIME (\%) & & & & & \\
\hline Northern Districts & 3.9 & 0.3 & - & 2.4 & 0.1 & - \\
\hline South/Midland Districts & 8.1 & 3.3 & - & 3.6 & 0.5 & - \\
\hline
\end{tabular}


Table 7 Real pay cyclicality of timeworkers and pieceworkers by EEF northern and southern/midland districts, 1927-1937

\begin{tabular}{|c|c|c|c|c|c|c|c|c|}
\hline & \multicolumn{2}{|c|}{ Standard hourly wage } & \multicolumn{2}{|c|}{ Hourly earnings } & \multicolumn{2}{|c|}{ Weekly hours } & \multicolumn{2}{|c|}{ Weekly earnings } \\
\hline & $\begin{array}{c}\text { Northern } \\
\text { Districts }\end{array}$ & $\begin{array}{c}\text { Southern/ } \\
\text { Midland } \\
\text { Districts }\end{array}$ & $\begin{array}{c}\text { Northern } \\
\text { Districts }\end{array}$ & $\begin{array}{c}\text { Southern/ } \\
\text { Midland } \\
\text { Districts }\end{array}$ & $\begin{array}{l}\text { Northern } \\
\text { Districts }\end{array}$ & $\begin{array}{c}\text { Southern/ } \\
\text { Midland } \\
\text { Districts }\end{array}$ & $\begin{array}{l}\text { Northern } \\
\text { Districts }\end{array}$ & $\begin{array}{c}\text { Southern/ } \\
\text { Midland } \\
\text { Districts }\end{array}$ \\
\hline & \multicolumn{8}{|c|}{ Estimates of $\Delta \mathrm{U}$ using national EEF unemployment rates" } \\
\hline Time-rated workers & $\begin{array}{c}-0.138 \\
(0.270)\end{array}$ & $\begin{array}{c}0.037 \\
(0.115)\end{array}$ & $\begin{array}{c}-0.280 \\
(0.300)\end{array}$ & $\begin{array}{l}-0.162 \\
(0.160)\end{array}$ & $\begin{array}{c}-0.976 * * \\
(0.337)\end{array}$ & $\begin{array}{c}-0.815^{* *} \\
(0.301\end{array}$ & $\begin{array}{l}-1.256^{*} \\
(0.506)\end{array}$ & $\begin{array}{l}-0.977 * \\
(0.422)\end{array}$ \\
\hline \multirow[t]{2}{*}{ Piece-rated workers } & - & - & $\begin{array}{c}-0.302^{* *} \\
(0.089)\end{array}$ & $\begin{array}{c}-0.283^{* *} \\
(0.072)\end{array}$ & $\begin{array}{c}-0.747 \\
(0.439)\end{array}$ & $\begin{array}{c}-0.692 * * \\
(0.261)\end{array}$ & $\begin{array}{l}-1.049 * \\
(0.501)\end{array}$ & $\begin{array}{c}-0.975^{* *} \\
(0.241)\end{array}$ \\
\hline & \multicolumn{8}{|c|}{ Estimates of $\Delta \mathbf{U}$ using EEF district unemployment rates } \\
\hline Time-rated workers & $\begin{array}{c}0.018 \\
(0.037)\end{array}$ & $\begin{array}{c}-0.161 \\
(0.117)\end{array}$ & $\begin{array}{c}-0.043 \\
(0.030)\end{array}$ & $\begin{array}{c}-0.163 \\
(0.094)\end{array}$ & $\begin{array}{c}-0.601^{* *} \\
(0.191)\end{array}$ & $\begin{array}{c}-0.112 \\
(0.237)\end{array}$ & $\begin{array}{c}-0.643^{* *} \\
(0.184)\end{array}$ & $\begin{array}{c}-0.276 \\
(0.237)\end{array}$ \\
\hline Piece-rated workers & - & - & $\begin{array}{c}-0.240 * * \\
(0.058)\end{array}$ & $\begin{array}{c}-0.638 * * \\
(0.189)\end{array}$ & $\begin{array}{c}-0.668 * \\
(0.318)\end{array}$ & $\begin{array}{c}0.137 \\
(0.324)\end{array}$ & $\begin{array}{c}-0.909 * * \\
(0.321)\end{array}$ & $\begin{array}{l}-0.502 \\
(0.425)\end{array}$ \\
\hline
\end{tabular}

Notes: Robust standard errors in brackets with ${ }^{* *}(*)$ indicating $0.001(0.005)$ significance on two-tail test. " Using consumer price index as deflator. See Table 2 for definitions of the make up of two district groups. Using national unemployment, there are 1894 timeworkers in northern districts in step 1 estimation and 11 observations in step 2 (i.e. 1894, 11). For timeworkers in southern/midland districts we have (943 (11). The respective numbers for pieceworkers are 1280 (11) and 1053 (11). The equivalent numbers for timeworkers are (2410, 11) and for pieceworkers 2410,11$)$. Using district unemployment rates, there are $(3589,305)$ observations for total workers, $(1876,305)$ timeworkers, and $(1713,285)$ pieceworkers. Using district unemployment rates (north), (south/midlands) we have: timeworkers $(1129,11),(678,109)$; pieceworkers $(845,169),(791,105)$. 